\title{
Leisure time behaviors: Prevalence, correlates and associations with overweight in Brazilian adults. A cross-sectional analysis
}

\author{
RÔMULO A. FERNANDES ${ }^{1}$, DIEGO G. D. CHRISTOFARO², \\ JULIANO CASONATO ${ }^{3}$, CLARA S. COSTA ROSA ${ }^{4}$, \\ FELIPE F. COSTA ${ }^{5}$, ISMAEL F. FREITAS JÚNIOR ${ }^{4}$, \\ HENRIQUE LUIZ MONTEIRO ${ }^{1}$, ARLI RAMOS DE OLIVEIRA ${ }^{3}$
}

\begin{abstract}
Background: Television viewing (TV viewing) is an important indicator of physical inactivity. Aim: To analyze the prevalence of different leisure time behaviors and $T V$ viewing among healthy adults and their association with overweight. Material and Methods: Cross sectional survey in which 1061 females and 925 males aged 30 years old or more, answered a self administered questionnaire about physical activity. Respondents were classified according to frequency participation in sports, walking, cycling and TV viewing. Body mass index (BMI) was derived from self reported weight and height. Results: Less than $30 \%$ of individuals participated regularly in sports and less than 15 and 5\% reported a high frequency of walking and cycling, respectively. Subjects regularly engaged in sports had a lower BMI. After adjustments, low cycling frequency and high TV viewing were associated with overweight in men and women, respectively. Conclusions: The prevalence of physical inactivity during leisure time is high among Brazilian adults and associated to obesity.
\end{abstract}

(Rev Med Chile 2010; 138: 29-35).

Key words: Brazil; Cross-sectional study; Overweight; Sports.

\section{Asociación entre actividad física en tiempo libre con sobrepeso en adultos sanos}

Antecedentes: Ver televisión tiene una estrecha asociación con sedentarismo. Objetivo: Evaluar las actividades de tiempo libre de adultos sanos y el hábito de ver televisión y su asociación con sobrepeso. Material y Métodos: Estudio de corte transversal en el cual 1.061 mujeres y 925 hombres de 30 años de edad y mas contestaron una encuesta auto administrada acerca de actividad física en tiempo libre. Los sujetos fueron clasificados de acuerdo a la frecuencia con que practicaban deportes, caminaban, andaban en bicicleta y veían televisión. El indice de masa corporal (IMC) se calculó utilizando el peso y talla que los sujetos informaron tener. Resultados: Menos del 30\% de los individuos practicaban deportes regularmente y menos del 15

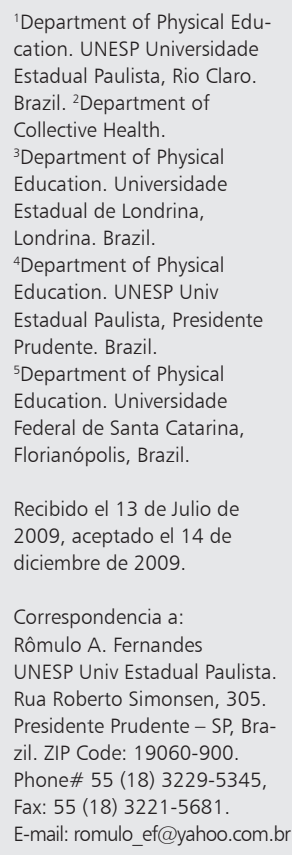

'Department of Physical Education. UNESP Universidade Estadual Paulista, Rio Claro. Brazil. ${ }^{2}$ Department of Collective Health.

${ }^{3}$ Department of Physical Education. Universidade Estadual de Londrina, Londrina. Brazil. ${ }^{4}$ Department of Physical Education. UNESP Univ Estadual Paulista, Presidente Prudente. Brazil. ${ }^{5}$ Department of Physical Education. Universidade Federal de Santa Catarina, Florianópolis, Brazil.

Recibido el 13 de Julio de 2009, aceptado el 14 de diciembre de 2009.

Correspondencia a:

Rômulo A. Fernandes

UNESP Univ Estadual Paulista. Rua Roberto Simonsen, 305. Presidente Prudente - SP, Brazil. ZIP Code: 19060-900. Phone\# 55 (18) 3229-5345, Fax: 55 (18) 3221-5681.

E-mail: romulo_ef@yahoo.com.br 
y $5 \%$ informaron caminar o andar en bicicleta frecuentemente. Los individuos que practicaban deportes en forma regular tenían un IMC menor. Después de ajustar los datos, una baja frecuencia de ciclismo y una alta frecuencia de ver televisión, se asociaron con sobrepeso en hombres y mujeres, respectivamente. Conclusiones: Existe una asociación entre falta de actividad física recreativa y sobrepeso en este grupo de adultos.

$\mathrm{O}$ verweight and physical inactivity are two risk factors, which present strong relationship between them and have been associated with a variety of unhealthy outcomes ${ }^{1-3}$. Television viewing (TV viewing) is an important indicator of physical inactivity, because the number of television sets per person increased following the overweight trend ${ }^{4}$ and frequently it is associated with adiposity and metabolic risks during adulthood ${ }^{5,6}$.

A conceptual model to explain the association between sedentary behavior and cardiovascular risk factors could be the decreased physical activity level (PAL) which would be associated with increased time spent in sedentary behavior, such as TV viewing. However, some authors have indicated the existence of a dissociation between amount of time spent in physical activity during leisure time and TV viewing and hence, that TV viewing and PAL should be regarded as separate behavior that relate to different cardiovascular risk factors ${ }^{5}$.

Few studies, however, have considered active behavior and TV viewing as separated entities and explored its impacts on body composition. Moreover, most of these were carried out in highincome countries, where physical activity patterns are different from those observed within low and middle-income ones ${ }^{7}$.

In developing countries, this issue has not been the focus of studies and, consequently, there is a lack of data about it. Thus, the purposes of the presented study were (i) to analyze the prevalence/ correlates of different leisure time behavior and (ii) to investigate the association between overweight and both active and inactive behavior as separate entities.

\section{Methods}

Sample: A cross-sectional study with adults ( $\geq 30$ year-old) residents in Presidente Prudente
( 200.000 habitants), Brazil, was carried out from July to October 2007. The sample size of 550 subjects was estimated assuming a physical activity prevalence in Brazilian adults of $59 \%{ }^{8}$ (error of 4.1 percentage points), power of at least $80 \%$ to detect differences and significance of $5 \%$. However, the number of individuals actually enrolled in the study was much higher $(\mathrm{n}=1.986$ subjects of both genders), because this study was part of another larger public health survey.

The sample was primarily contacted through children from six out of 36 schools, randomly selected. The students (aged 11 to 17 years) received a written informed consent and two questionnaires (behavior during leisure time and anthropometric data) which were sent to their parents, and were fulfilled at home. Out of the 2200 eligible students, 1.001 (57\%) returned with theirs parents' data, totaling a sample size of 1.986 subjects (female $\mathrm{n}=1.061$ and male $\mathrm{n}=925 ; \mathrm{p}=0.002$ ) aged 30 and over. The study was approved by the Ethics Committee for Research of the Sao Paulo State University from Presidente Prudente and written informed consent was obtained from participants prior the survey.

\section{Nutritional status: Overweight and obesity}

Both parents self-reported their body weight, height and schooling (years of formal education). The body mass index (BMI), body weight, in kilograms, divided by the square of the height, in meters, was used to classify the nutritional status of the subjects in overweight $\left(\geq 25\right.$ and $\left.<30 \mathrm{~kg} / \mathrm{m}^{2}\right)$ and obesity $\left(\geq 30 \mathrm{~kg} / \mathrm{m}^{2}\right)$.

\section{Physical activity: sports, active leisure time beha- vior and $T V$ viewing}

Regular participation in sports was defined as all moderate/vigorous intensity sport activities enrolled for, at least, three months before evaluation. Active and sedentary behaviors were also collected utilizing the same questionnaire? ${ }^{9}$. The 
Leisure behaviors and overweight - R. A. Fernandes et al

Table 1. Sample's general characteristics grouped into gender and frequency of leisure behaviors

\begin{tabular}{|c|c|c|c|c|c|c|}
\hline & \multicolumn{3}{|c|}{ MEN (n = 925) } & \multicolumn{3}{|c|}{ WOMEN $(n=1.061)$} \\
\hline & LOW-F & MID-F & HIGH-F & LOW-F & MID-F & HIGH-F \\
\hline & Median(IR) & Median(IR) & Median(IR) & Median(IR) & Median(IR) & Median(IR) \\
\hline & \multicolumn{3}{|c|}{ Walking } & \multicolumn{3}{|c|}{ Walking } \\
\hline Age (years) & $40.7(8.8)$ & $42.2(9.8)$ & $43.1(11.8)^{*}$ & $39.1(8.7)$ & $39.1(8)$ & $40.2(7.9)$ \\
\hline Height (m) & $1.72(0.10)$ & $1.73(0.10)$ & $1.73(0.10)$ & $1.60(0.08)$ & $1.60(0.09)$ & $1.60(0.12)$ \\
\hline Weight (kg) & $80.1(18)$ & $78.1(18)$ & $74.1(18.5)^{*}$ & $64.5(16)$ & $65(14)$ & $63.1(13)$ \\
\hline \multirow[t]{2}{*}{ BMI $\left(\mathrm{kg} / \mathrm{m}^{2}\right)$} & $26.5(4.9)$ & $26.2(4.9)$ & $25.1(4.5)^{*}$ & $24.9(6.1)$ & $24.8(5.1)$ & $23.8(5.5)$ \\
\hline & \multicolumn{3}{|c|}{ Cycling } & \multicolumn{3}{|c|}{ Cycling } \\
\hline Age (years) & $41.8(9.5)$ & $40.7(9.2)$ & $40.7(7.5)$ & $39.5(8.5)$ & $37.5(6.8)$ & $37.4(10.6)^{*}$ \\
\hline Height (m) & $1.73(0.09)$ & $1.70(0.11)$ & $1.70(0.10)^{*}$ & $1.60(0.09)$ & $1.63(0.09)$ & $1.66(0.08)^{*}$ \\
\hline Weight (kg) & 80.1 (19) & $76(17)$ & $76(15)^{*}$ & $65(14)$ & $63(16)$ & $65(7.2)$ \\
\hline \multirow[t]{2}{*}{ BMI $\left(\mathrm{kg} / \mathrm{m}^{2}\right)$} & $26.3(4.8)$ & $25.9(4.2)$ & $24.8(4.6)^{*}$ & $24.8(5.5)$ & $24.3(5.1)$ & $23.3(6.7)$ \\
\hline & \multicolumn{3}{|c|}{ TV viewing } & \multicolumn{3}{|c|}{ TV viewing } \\
\hline Age (years) & $42.7(13.3)$ & $41.4(9.2)$ & $41.1(8.2)$ & $39.1(8.2)$ & $39.3(8.1)$ & $38.2(9.1)$ \\
\hline Height (m) & $1.73(0.10)$ & $1.72(0.10)$ & $1.72(0.11)$ & $1.60(0.08)$ & $1.60(0.09)$ & $1.60(0.10)$ \\
\hline Weight (kg) & $80(18)$ & $78(17)$ & $79.5(19.5)$ & $62(14.7)$ & $64(14)$ & $65(17)^{*}$ \\
\hline BMI $\left(\mathrm{kg} / \mathrm{m}^{2}\right)$ & $26.9(5.3)$ & $26.1(4.7)$ & $26.3(5.6)$ & $24.1(4.7)$ & $24.4(5.1)$ & $25.1(6.5)^{*}$ \\
\hline
\end{tabular}

$*=$ Kruskal-Wallis test with $\mathrm{p}<0.05 ; \mathrm{LOW}-\mathrm{F}=$ Low frequency; MID-F= Mid frequency; HIGH-F= High frequency; $\mathrm{BMI}=\mathrm{Body}$ mass index.

Table 2. Association between gender, sports and leisure time behaviors among adults

\begin{tabular}{|c|c|c|c|c|c|}
\hline & & $\begin{array}{l}\text { Men } \\
\text { N (\%) }\end{array}$ & $\begin{array}{c}\text { Women } \\
\text { N (\%) }\end{array}$ & $\chi^{2}$ & $\begin{array}{c}\text { Men } \\
\text { PR }(95 \% \mathrm{Cl})\end{array}$ \\
\hline \multirow[t]{3}{*}{ N. Status } & Normal BMI & $314(33.9)$ & $577(54.4)$ & 0.001 & 1.00 \\
\hline & Overweight & $439(47.5)$ & $347(32.7)$ & & $1.58(1.42-1.76)$ \\
\hline & Obesity & $172(18.6)$ & $137(12.9)$ & & $1.57(1.38-1.80)$ \\
\hline \multirow[t]{3}{*}{ Walking } & LOW-F & $466(50.7)$ & $460(43.5)$ & 0.001 & 1.00 \\
\hline & Mid-F & 359 (38.9) & $471(44.5)$ & & $0.85(0.77-0.94)$ \\
\hline & High-F & $100(10.4)$ & $130(12)$ & & $0.85(0.72-1.00)$ \\
\hline \multirow[t]{3}{*}{ Cycling } & LOW-F & $672(73.7)$ & $924(88.1)$ & 0.001 & 1.0 \\
\hline & Mid-F & $196(20.9)$ & $116(10.5)$ & & $1.50(1.35-1.67)$ \\
\hline & High-F & $57(5.4)$ & $21(1.4)$ & & $1.82(1.57-2.11)$ \\
\hline \multirow[t]{3}{*}{ TV viewing } & LOW-F & $124(13.1)$ & $135(12.8)$ & 0.806 & 1.0 \\
\hline & Mid-F & $558(60.7)$ & $655(62)$ & & $0.97(0.84-1.12)$ \\
\hline & High-F & $243(26.2)$ & $268(25.2)$ & & $1.00(0.85-1.18)$ \\
\hline \multirow[t]{2}{*}{ Sports } & NO & $685(74.1)$ & $829(78.1)$ & 0.041 & 1.0 \\
\hline & YES & $240(25.9)$ & $232(21.9)$ & & $1.12(1.01-1.24)$ \\
\hline
\end{tabular}

LOW-F= Low frequency; MID-F= Mid frequency; HIGH-F= High frequency; PR= Prevalence ratio; $95 \% \mathrm{Cl}=95 \%$ confidence interval; N. STATUS = Nutritional status. BMI= Body mass index. 
frequency (never; seldom; sometimes; often; very often) of these behaviors (active $=$ walking and cycling; sedentary $=\mathrm{TV}$ viewing) were collected and grouped into three categories: Low frequency $($ LOW-F $=$ never and seldom $)$, Mid frequency (MID-F= sometimes and often), and High frequency (HIGH-F= very often).

\section{Data's reliability}

To test the reproducibility of the parents' self reported data, thirty parents were randomly selected to be interviewed at school. All the interviews at school were performed by a trained researcher in a reserved room (questionnaires and anthropometry). The kappa coefficient between the two measures was high (schooling $[k=1.0] ; \mathrm{BMI} \geq 25$ $\mathrm{kgm}^{2}[k=0.85]$; regular participation in sports: yes/no $[k=0.80])$.

\section{Statistical procedure}

Normality was assessed and rejected (K-S test). Thus, numerical variables were compared with both Kruskal-Wallis and Mann-Whitney tests. The chi-squared test $\left(\chi^{2}\right)$ was used to evaluate associations between overweight and all leisure time behaviors. After the $\chi^{2}$ use, the Poisson regression with robust variance ${ }^{10}$, represented by the prevalence ratio (PR) and 95\% confidence interval (95\%CI), was carried out. For the categorical variables, the agreement level was analyzed by the Kappa statistic. STATA 8.0 was used in all statistical procedures and significance level was set at 5\%.

\section{Results}

Table 1 shows the general characteristics of the sample grouped into gender and frequency of leisure time behaviors. For male gender, the subjects situated in the highest frequency of walk $(\mathrm{p}=0.001)$ and cycle $(\mathrm{p}=0.010)$ presented BMI values significantly lower than the two other lowest frequency groups. For female gender, the group located in highest frequency of TV viewing presented the highest BMI values $(\mathrm{p}=0.001)$. The regular participation in sports was structured as a dichotomized variable (yes/no), and in both male (Yes: $25.8 \mathrm{~kg} / \mathrm{m}^{2}$ and No: $26.5 \mathrm{~kg} / \mathrm{m}^{2} ; \mathrm{p}=0.021$ )

Table 3. Association between overweight and different leisure time behaviors among Brazilian adults

\begin{tabular}{|c|c|c|c|c|}
\hline & \multicolumn{2}{|c|}{$\begin{array}{l}\text { Men }(n=925) \\
\text { Overweight }\end{array}$} & \multicolumn{2}{|c|}{$\begin{array}{c}\text { Women }(n=1061) \\
\text { Overweight }\end{array}$} \\
\hline & $\begin{array}{c}\text { Crude PR } \\
(95 \% \mathrm{Cl})\end{array}$ & $\begin{array}{c}\text { Adjusted PR } \\
(95 \% \mathrm{Cl})\end{array}$ & $\begin{array}{c}\text { Crude PR } \\
(95 \% \mathrm{Cl})\end{array}$ & $\begin{array}{c}\text { Adjusted PR } \\
(95 \% \mathrm{Cl})\end{array}$ \\
\hline & \multicolumn{2}{|c|}{ Walking } & \multicolumn{2}{|c|}{ Walking } \\
\hline Low-F & Reference 1.00 & Reference 1.00 & Reference 1.00 & Reference 1.00 \\
\hline Mid-F & $0.94(0.85-1.04)$ & $0.92(0.83-1.02)$ & $0.91(0.79-1.05)$ & $0.92(0.80-1.06)$ \\
\hline \multirow[t]{2}{*}{ High-F } & $0.78(0.64-0.95)^{*}$ & $0.78(0.65-0.95)^{*}$ & $0.86(0.68-1.08)$ & $0.85(0.67-1.06)$ \\
\hline & \multicolumn{2}{|c|}{ Cycling } & \multicolumn{2}{|c|}{ Cycling } \\
\hline Low-F & Reference 1.00 & Reference 1.00 & Reference 1.00 & Reference 1.00 \\
\hline Mid-F & $0.94(0.83-1.05)$ & $0.96(0.85-1.09)$ & $0.88(0.70-1.12)$ & $0.89(0.70-1.13)$ \\
\hline \multirow[t]{2}{*}{ High-F } & $0.74(0.56-0.98)^{*}$ & $0.80(0.60-1.06)$ & $0.71(0.34-1.47)$ & $0.66(0.32-1.36)$ \\
\hline & \multicolumn{2}{|c|}{ TV viewing } & \multicolumn{2}{|c|}{ TV viewing } \\
\hline Low-F & Reference 1.00 & Reference 1.00 & Reference 1.00 & Reference 1.00 \\
\hline Mid-F & $0.98(0.85-1.12)$ & $0.96(0.84-1.11)$ & $1.17(0.93-1.48)$ & $1.17(0.93-1.48)$ \\
\hline \multirow[t]{2}{*}{ High-F } & $0.97(0.83-1.13)$ & $0.98(0.84-1.15)$ & $1.39(1.09-1.78)^{*}$ & $1.34(1.05-1.72)^{*}$ \\
\hline & \multicolumn{2}{|c|}{ Sports } & \multicolumn{2}{|c|}{ Sports } \\
\hline NO & Reference 1.00 & Reference 1.00 & Reference 1.00 & Reference 1.00 \\
\hline YES & $0.90(0.80-1.01)$ & $0.87(0.78-0.98)^{*}$ & $0.86(0.72-1.02)$ & $0.88(0.74-1.05)$ \\
\hline
\end{tabular}

$*=p<0.05 ; \mathrm{LOW}-\mathrm{F}=$ low frequency; MID-F= Mid frequency; $\mathrm{HIGH}-\mathrm{F}=$ high frequency; $\mathrm{PR}=$ prevalence ratio; $95 \% \mathrm{Cl}=95 \%$ confidence interval; Adjusted PR= adjusted by schooling. 
Leisure behaviors and overweight - R. A. Fernandes et al

Table 4. Multivariate model for association between overweight and different leisure time behaviors among Brazilian adults

\begin{tabular}{|c|c|c|c|c|}
\hline & & \multicolumn{3}{|c|}{ Presence of Overweight or Obesity } \\
\hline & & Men $(\mathrm{n}=925)$ & Women (n = 1.061) & Total $(n=1.986)$ \\
\hline & & Adjusted PR $(95 \% \mathrm{Cl})$ & Adjusted PR $(95 \% \mathrm{Cl})$ & Adjusted PR $(95 \% \mathrm{Cl})$ \\
\hline \multirow[t]{3}{*}{ Walking } & LOW-F & Reference 1.00 & Reference 1.00 & Reference 1.00 \\
\hline & Mid-F & $0.95(0.86-1.05)$ & $0.95(0.82-1.10)$ & $0.92(0.84-1.01)$ \\
\hline & High-F & $0.85(0.69-0.99)^{*}$ & $0.91(0.71-1.17)$ & $0.83(0.71-0.98)^{*}$ \\
\hline \multirow[t]{3}{*}{ Cycling } & LOW-F & Reference 1.00 & Reference 1.00 & Reference 1.00 \\
\hline & Mid-F & $0.97(0.86-1.10)$ & $0.90(0.71-1.15)$ & $1.02(0.91-1.14)$ \\
\hline & High-F & $0.82(0.61-1.11)$ & $0.65(0.32-1.33)$ & $0.84(0.64-1.12)$ \\
\hline \multirow[t]{3}{*}{ TV viewing } & LOW-F & Reference 1.00 & Reference 1.00 & Reference 1.00 \\
\hline & Mid-F & $0.95(0.83-1.10)$ & $1.23(0.96-1.57)$ & $1.06(0.92-1.21)$ \\
\hline & High-F & $0.98(0.84-1.15)$ & $1.42(1.09-1.83)^{*}$ & $1.16(1.00-1.34)^{*}$ \\
\hline \multirow[t]{2}{*}{ Sports } & NO & Reference 1.00 & Reference 1.00 & Reference 1.00 \\
\hline & YES & $0.91(0.80-1.02)$ & $0.95(0.79-1.15)$ & $0.95(0.85-1.06)$ \\
\hline
\end{tabular}

$*=p<0.05 ;$ LOW-F= low frequency; MID-F= Mid frequency; $\mathrm{HIGH}-\mathrm{F}=$ high frequency; $\mathrm{PR}=$ prevalence ratio; $95 \% \mathrm{Cl}=95 \%$ confidence interval; Adjusted PR= adjusted by schooling.

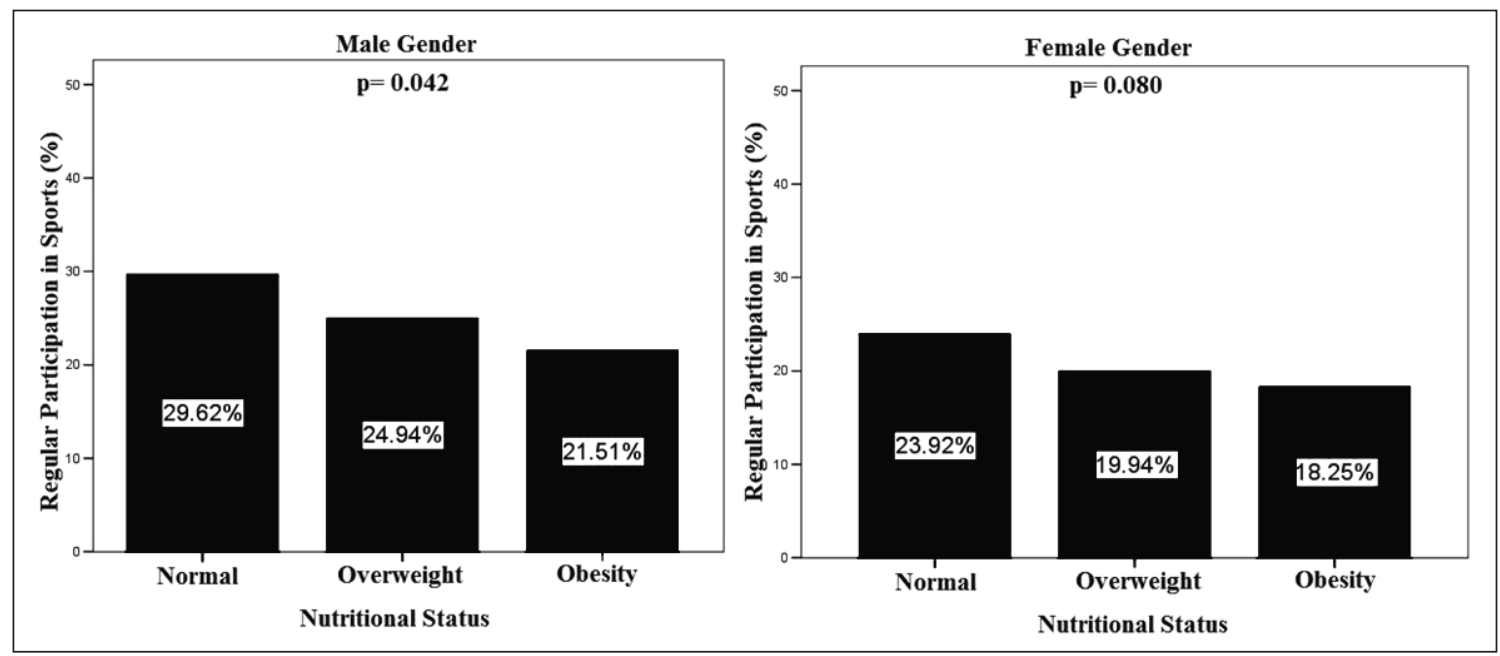

Figure 1. Association between regular participation in sports and nutritional status in Brazilian adults of both genders.

and female gender (Yes: $23.9 \mathrm{~kg} / \mathrm{m}^{2}$ and No: 24.6 $\left.\mathrm{kg} / \mathrm{m}^{2} ; \mathrm{p}=0.048\right)$, the BMI medians values of the group "yes for regular participation in sports" were significantly lower than the other group.

Individuals were classified as overweight or obese $66.1 \%(\mathrm{n}=611)$ in male gender and $45.6 \%$ $(\mathrm{n}=484)$ in female gender $(\mathrm{p}=0.001)$. Men presented higher rate of engagement in cycling and regular participation in sports during leisure time than women (Table 2). During leisure time, women were more engaged in walk than men only in MID-F group. The associations between nutritional status and each leisure time behaviors are shows in Table 3. Even after adjusts for the confounders, there was an association between overweight and walking/sports for male gender and between overweight and TV viewing on female gender. 
Figure 1 presents the associations between regular participation in sports and nutritional status. The positive answer for regular participation in sports was negatively associated with obesity in males and marginally significant in females. In the final regression model, sedentary and active behaviors were simultaneously entered in the Poisson regression as independent variables (Table 4). The association between overweight and walking in men and overweight and TV Viewing in women remained significant after this new adjustment.

\section{Discussion}

The prevalence of overweight/obesity was high $(55.1 \%)$ in this population sample and higher in men $(66.1 \%)$ than in women $(45.6 \%)$. These rates are higher than those observed in 2003 in Brazilian men $(49 \%)$ and women $(52.8 \%)^{11}$ and are similar to Australians' self-reported data, where the overall overweight rate was $49.9 \%$ (male $=60 \%$ and female $=45 \%)^{12}$. In agreement with our data, the last national surveys (1973, 1989, and 2003) indicated that overweight increased and constitutes a public health problem which must be closely monitored.

In developing countries, the prevalence of physical inactivity among adults is high ${ }^{8,13}$, and our data are similar, since during leisure time less than $30 \%$ of the analyzed sample participated regularly of sports, and less than $15 \%$ and $5 \%$ reported highest frequency of walking and cycling, respectively. Approximately one out of ten (11.2\%) subjects reported a high frequency of walking while only $3.3 \%$ reported a high frequency of cycling. This higher practice of walking than cycling was also reported by Wendel-Vos et $\mathrm{al}^{14}$, in adults from a Dutch town. There is not data about cycling in Brazilian population, however, walking is a common physical activity in developed and developing nations, as well as is an inexpensive/more accessible activity than cycling, characteristics which could explain this more elevated practice of walking in the general population.

The gender is an important confounder in the epidemiology of physical activity, where men are more physically active than women ${ }^{5,13-15}$. In our sample, both highest frequency of cycling and regular participation of sports were associated with male gender, while walking frequency (HIGH-F) was similar in both genders. The observed dis- sociation between walking and gender, and the association between male gender and sports are in agreement with previous researches in Brazilian adults. Hallal et al ${ }^{13}$, reported that men walk more than women in all-domains of physical activity, but these differences did not remain significant in the leisure time activities. Furthermore, men are more likely to practice physical activities of vigorous intensity such as sports and exercise, while women practice more non structured/ light activities such as dance and housework ${ }^{5,16}$. Recently, Gonçalves et $\mathrm{a}^{17}$, reported that Brazilian male adolescents have more social and family support to engage in physical activities than female. Moreover, in Brazil the occurrence of perceived personal barriers to engagement in leisure-time behaviors is more frequent in the female gender ${ }^{7}$.

In both genders high PAL has been associated with reduced adiposity/plasma lipid profile ${ }^{5,18}$, and TV viewing with increased metabolic risk factors ${ }^{5,6}$. When numerical variables are analyzed, the information from our study agreed with these previous data, where highest BMI values were observed in men grouped in lowest frequency group for walking and cycling. However, this difference was observed only in males, because in women only highest frequency group for TV viewing presented significantly increased BMI values. When the categorized variables are analyzed in men, the highest frequency group for cycling (crude model) and walking were associated with lower occurrence of overweight. In the adjusted model, after adjustment for confounders, only walking remained statistically significant. In females, only TV viewing was associated with a higher frequency of overweight. In both genders, the effects of walking and TV viewing remained significant even after analysis of all leisure time behaviors simultaneously as independent variables, indicating independent effects over overweight among these variables and agreeing with Aadahl et $\mathrm{al}^{5}$.

TV viewing seems to be positively associated with adiposity in different ways (e.g., unhealthy eating or snacking), while the physical activity is associated with lower adiposity due to larger use of nutrients as source of energy to perform physical activity. Cleland et al. ${ }^{19}$ verified that the association between TV viewing and waist circumference was attributed partially to the consumption of foods while TV viewing, but not for the reduction of the total physical activity. 
In the present study, the subjects of both genders that regularly engaged in sports of moderate or vigorous intensity, at least three months before the survey, presented lower BMI values than those not engaged. In addition, although it was not possible to analyze accurately the intensity or a prior period of engagement in walking and cycling, our data showed that the highest frequency of PA practice was associated to overweight, indicating the relevance of inclusion the PA in the people lifestyle, instead of only increasing the intensity.

The present study has several strengths, such as its large sample size and reliability of its selfreported measures; but its limitations also should be recognized. Thus, the cross-sectional design cannot establish a causal relationship between independent variables and overweight and for this reason it constitutes the main limitation of this survey.

In conclusion, our data indicate that the prevalence of physical inactivity during leisure time is high among Brazilian adults and also is strongly associated with gender. Furthermore, TV viewing and active behaviors during leisure time are dissociated entities and, also, differently and independently associated with overweight in each gender.

Acknowledgments: The CAPES by the financial support.

\section{References}

1. Chenoweth D, Leutzinger J. The economic cost of physical inactivity and excess weight in American adults. J Phys Act Health 2006; 3: 148-63.

2. Grover SA, Coupal L, Lowensteyn I. Determining the cost-effectiveness of preventing cardiovascular disease: are estimates calculated over the duration of a clinical trial adequate? Can J Cardiol 2008; 24: 261-6.

3. Bakhai A. How to cost cardiovascular care. Heart 2008; 94: 549-51.

4. Wang Y, Monteiro C, Popkin BM. Trends of obesity and underweight in older children and adolescents in the United States, Brazil, China, and Russia. Am J Clin Nutr 2002; 75: 971-7.

5. Aadahl M, Kjaer M, Jorgensen T. Influence of time spent on TV viewing and vigorous intensity physical activity on cardiovascular biomarkers. The Inter 99 Study. Eur J Cardiovasc Prev Rehabil 2007; 14: 660-5.

6. Chang P, Li T, Wu M, Liu C, Li C, Chen C, et al. As- sociation between television viewing and the risk of metabolic syndrome in a community-based population. BMC Public Health 2008; 8: 193.

7. Reichert FF, Barros AJ, Domingues MR, Hallal PC. The role of perceived personal barriers to engagement in leisure-time physical activity. Am J Public Health 2007; 97: 515-9.

8. Hallal PC, Victora CG, Wells JC, Lima RC. Physical inactivity: prevalence and associated variables in Brazilian adults. Med Sci Sports Exerc 2003; 35: 1894-900.

9. Baecke JA, Burema J, Frijters JE. A short questionnaire for the measurement of habitual physical activity in epidemiological studies. Am J Clin Nutr 1982; 36: 936-42.

10. Barros AJ, Hirakata VN. Alternatives for logistic regression in cross-sectional studies: an empirical comparison of models that directly estimate the prevalence ratio. BMC Med Res Method 2003; 3: 21.

11. Monteiro CA, Conde WL, Popkin BM. Income-specific trends in obesity in Brazil: 1975-2003. Am J Public Health 2007; 97: 1808-12.

12. Sugyiama T, Healy GN, Salmon J, Owen N. Joint associations of multiple leisure-time sedentary behaviors and physical activity with obesity in Australian adults. Int J Behav Nutr Phys Act 2008; 5: 35.

13. Hallal PC, Azevedo MR, Reichert FF, Siqueira FV, Araujo CL, Victora CG. Who, when, and how much? Epidemiology of walking in a middle-income country. Am J Prev Med 2005; 28: 156-61.

14. Wendel-Vos W, Schut AJ, De Niet R, Boshuizen HC, Saris WH, Kromhout D. Factors of the physical environment associated with walking and bicycling. Med Sci Sports Exerc 2004; 36: 725-30.

15. Azevedo MR, Araujo CL, Reichert FF, Siqueira FV, da Silva MC, Hallal PC. Gender differences in leisure-time physical activity. Int J Public Health 2007; 52: 8-15.

16. Azevedo MR, Araujo CL, Silva MC, Hallal PC. Tracking of physical activity from adolescence to adulthood: a population-based study. Rev Saude Publica 2007; 41: 69-75.

17. Gonçalves H, Hallal PC, Amorim TC, Araújo CL, Menezes AM. Sociocultural factors and physical activity level in early adolescence. Rev Panam Salud Publica 2007; 22: 246-53.

18. Guedes DP, Gonçalves LA. Impact of the physical activity on lipid profile in adults. Arq Bras Endocrinol Metab 2007; 51: 72-8.

19. Cleland VJ, Schimidt MD, Dwyer T, Venn AJ. Television viewing and abdominal obesity in young adults: is the association mediated by food and beverage consumption during viewing time or reduced leisure-time physical activity? Am J Clin Nutr 2008; 87: 1148-55. 